\title{
硫化アンモニウムを用いるアンチモン，スズ，ヒ素イオンの ペーパークロマトグラフィー
}

\author{
五島 交韶，石野 二三枝*
}

(1973 年 8 月 23 日受理)

\begin{abstract}
ペーパークロマトグラフィーによるフンチモン，スズ，ヒ素イオンの相互分離のために硫化アンモニ ウム水溶液を用いた展開溶媒系について検討した.

硫化アンモニウム溶液（黄色)ーピリジン $(2: 3 \mathrm{v} / \mathrm{v})$ で $5 \mathrm{~cm}, 30$ 分間，上昇法により展開を行なう とアンチモン $\left(R_{f}\right.$ 值 0.28$)$ とスズ $\left(R_{f}\right.$ 值 0.94$)$ とは各イオンの酸化数には無関係に分離されるが, 3 価の七素が共存する場合にはアンチモンと重なる.

アンチモン，スズ，七素の相互分離の場合には硫化アンモニウム溶液（黄色）-ピリジン-2, 4, 6-コリ ジン $(35: 55: 10 \mathrm{v} / \mathrm{v})$ で $7 \mathrm{~cm}, 60$ 分間, 上昇法により展開する. 各 $R_{f}$ 值はスズ(II, IV) 0.96 , ヒ素(III) $0.42 ＼mathrm{~ フ ン チ モ ン(I I I ， V) ~ 0.24 ， ~ ヒ 素(V) ~} 0$ となる. この場合七素(III) とアンチモン (III，V) は接近しているが，色調が異なるので両者の区別は容易である.

各スポットの位置は，展開終了後溶媒の乾燥につれて各硫化物の色調を呈するので発色のための操作 を必要としない。
\end{abstract}

\section{1 緒言}

ペーパークロマトグラフィーを用いた無機イオンの分 離については多くの報告が行なわれている. アンチモ ン，スズ，七素イオンの相互分離についてはブタノ一 ル, 塩酸, 過酸化水素水によるアンチモン $(\mathrm{V})$ とスズ (IV) の分離報告1) や炭酸アンモニウム水溶液によるア ンチモン $(\mathrm{III}) ，$ スズ(II)，七素(V) の分離報告2)，あ るいは硝酸飽和コリジンによる七素(III), アンチモン (III)，スズ(II，IV) の分離報告3) などが見られるが， いずれもイオンの酸化数をそろえるための処理として試 料の酸化あるいは還元の操作を必要としている.さらに 硝酸, 塩酸, ブタノールによるアンチモン(III), スズ $(\mathrm{IV}) ， 七$ 素(III) の分離報告4) では 10 時間以上の展開 時間を要する.

またアンチモンとスズのイオンは加水分解のためにテ ーリングや副スポットを生じやすいために相互分雄はか なり困難である。

本報交では展開溶媒として硫化アンモニウム水溶液を 用いアンチモン，スズ，七素をチオ酸塩として展開し， これらを相互分離することを試み，硫化アンモニウム溶

* 岐皁大学教育学部化学教室 : 岐阜県岐阜市長良城の 内
液（黄色）ーピリジン系の展開溶媒を用いた場合の分雖条 件について報告する.

\section{2 尖験}

\section{1 試薬ならびに試料の調製}

2.1.1 展開溶媒 硫化アンモニウム溶液としては怰 販の硫化アンモニウム溶液（無色，イオウ含量 $0.5 \%$ 以 上，および黄色，イオウ含量 $5 \%$ 以上）の JIS 規格試 薬 1 級品 (小宗化学薬品株式会社製) を用いた. ピリジ ンは試薬特級品， 2, 4, 6-コリジンはクロマト用試薬. そ の他の有機溶媒は陚薬 1 級品をそのまま使用した.

2.1.2 試料の調製 5 価のアンチモンは金属アンチ モンの $0.1000 \mathrm{~g}$ を王水に溶解し, 塩酸で希橎して, $6 \mathrm{~N}$ 塩酸 $1 \mathrm{~m} l$ 中に $5 \mathrm{mg}$ 含有する濃度に調製した. 3 価の アンチモン，スズ，拉よびヒ素の各陚料は三塩化アンチ モン，塩化符一スズ，塩化符二スズ，三酸化七素および 五酸化七素の特級碔盓を $12 N$ 塩酸に溶解したのち, 水 で希釈し， $6 N$ 塩酸 $1 \mathrm{~m} l$ 中に各金属イオンとして $5 \mathrm{mg}$ 含们する濃度に調製した。

標準混合試料溶液は $6 N$ 塩酸 $1 \mathrm{~m} l$ 中に各金属イオン として 3 価のアンチモン， 5 価のアンチモン， 2 価のス ズおよび 4 価のスズ各 $2 \mathrm{mg}$ を， 3 価のヒ素および 5 俩 の七素各 $5 \mathrm{mg}$ を含有する濃度に調製した。

その他の金属イオンの試料溶液は各硝酸塩の試薬特級 品を $6 N$ 塩酸 $1 \mathrm{~m} l$ 中に金属イオンとして各 $5 \mathrm{mg}$ 含 有寸る濃度に調製した。

2.1.3 沪紙東洋汇紙 No. 50 を使用した。

2.1.4 発色展閒終了後, 自然乾燥させれば各金属 
イオンの硫化物の虽色スポットが確㴔される。 5 俩のヒ 素については展開溶媒中に 2,4,6-コリジンを含屯埸介, しばらく放置するとスポットの㫦置に黄色のリングが現 われる，2,4,6-コリジンを含まない場合には呈色が認め られないので，展開溶媒を完全に乾燥させたのち，2\% モリブデン酸フンモニウムの $2 N$ 硫酸酸性溶液を噴霧 後, ただちに $2 \%$ 湓化籁一スズの $4 N$ 塩酸酸性溶液を 喷霧して現われる睍色の品色スポットで確認した。

\section{2 操作法}

$2 \cdot 1 \cdot 3$ で述べた沪紙の一端から $1 \mathrm{~cm}$ の所を原点とし， $2 \cdot 1 \cdot 2$ で调製した標準混合試料 $1 \mu l$ をガラス毛細管で 付着する. 展開溶媒として硫化アンモニウム溶液（黄 色)ービリジン-2, 4, 6-コリジン (35: $55: 10 \mathrm{v} / \mathrm{v})$ を用い 密閉容器中で上昇法により $7 \mathrm{~cm}$, 約 60 分間展開を行 なう。

\section{3 維果と考繁}

\section{1 展開溶媒の選択}

嫏開溶媒に硫化アンモニウム溶液の多を用いた㭶今, アンチモン，スズ，ヒ素イオンはチオ酸盐となり移動す るが，展開スポットは一群となり分離不可能である.

3 者の相互分離のために硫化アンモニウム溶液に加え る有機溶媒の種類について検湖した。硫化アンモニウム 溶液は無色, 黄色ともに検討したが，無色の場合には， いずれも $R_{f}$ 值が接近し，しかもアンチモンの加水分解 によるテーリングも認められるため分離不可能である.

Table I は硫化アンモニウム溶液（齿色）と有機溶媒 を $1: 1$ (v/v) に混合するか，または有機溶媒に硫化ア ンモニウムを飽和させた展開溶媒について検滆した絬果 である.

Table I から明らかなように, アルコールとの混合溶 媒では，炭素数が大きくなるほど $R_{f}$ 佃は小さくなる

Table I $R_{f}$ values of $\mathrm{Sb}, \mathrm{Sn}$ and $\mathrm{As}$ by paper chromatography

\begin{tabular}{|c|c|c|c|c|c|c|}
\hline \multirow{2}{*}{$\begin{array}{l}\text { Organic com- } \\
\text { ponent of } \\
\text { solvent }\end{array}$} & \multirow[b]{2}{*}{$\mathrm{Sb}^{3+}$} & \multirow[b]{2}{*}{$\mathrm{Sb}^{5+}$} & \multicolumn{2}{|c|}{$R_{f}$} & \multirow[b]{2}{*}{$\mathrm{As}^{3+}$} & \multirow[b]{2}{*}{$\mathrm{As}^{5+}$} \\
\hline & & & $\mathrm{Sn}^{2+}$ & $\mathrm{Sn}^{4+}$ & & \\
\hline Methanol & $0.6+\mathrm{T}$ & $0.61 \mathrm{~T}$ & $0.60 \mathrm{~T}$ & $0.61 \mathrm{~T}$ & 0.59 & $0.65^{\prime} \mathrm{T}^{\prime}$ \\
\hline Ethanol & 0.57 & 0.55 & 0.55 & 0.55 & 0.50 & 0.63 \\
\hline Propanol & 0.38 & 0.39 & 0.35 & 0.35 & 0.37 & 0.49 \\
\hline Butanol† & 0 & 0.02 & 0.02 & 0 & 0.01 & 0.03 \\
\hline Acetone & 0.38 & 0.41 & 0.78 & 0.78 & 0.31 & 0.40 \\
\hline $\begin{array}{l}\text { Methyl isobutyl } \\
\text { ketone }\end{array}$ & 0.88 & 0.89 & 0.84 & 0.81 & 0.83 & 0.92 \\
\hline Dioxan & 0.43 & 0.48 & 0.84 & 0.83 & 0.42 & 0.34 \\
\hline Pyridine & 0.38 & 0.36 & 0.95 & 0.91 & 0.39 & 0.14 \\
\hline 2, 4,6-Collidine $†$ & 0.05 & 0.10 & 0.67 & 0.75 & 0.08 & 0 \\
\hline
\end{tabular}

Solvents : A mixture of ammonium sulfide solution (yellow) and organic solvent $(1: 1 \mathrm{v} / \mathrm{v}) ; \quad \dagger$ Organic solvent saturated with ammonium sulfide (yellow) $\mathrm{T}$ : Tailing
が， $R_{f}$ 值は接近し，相互分離は不可能である. ジオキ サン，ピリジン，2，4，6-コリジンにおいてはスズのスポ ットとアンチモン，ヒ素のスポットの 2 群に分離可能で ある.しかしジオキサンの場合には拡散がやや大きいた め適当ではない。

\section{2 硫化アンモニウム溶液（黄色）とピリジンとの混} 合比

$3 \cdot 1$ で検討した結果から，展開溶媒に硫化アンモニウ ム溶液（黄色）とピリジンの混合溶媒を選び，その混合 比の変化とアンチモン，スズ，七素の $R_{f}$ 值の変化につ いて検討した. Fig. 1 にその結果を示す.

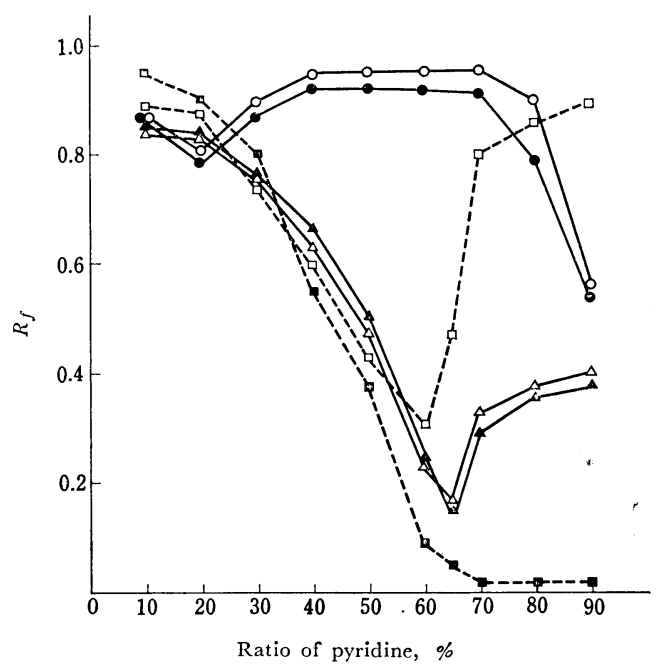

Fig. 1 Effect of amounts of pyridine

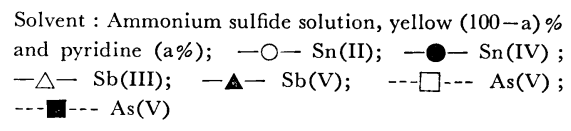

ピリジンの量が $30 \%$ 以下では $R_{f}$ 值が接近し相互分 離は困難である。また，70\% 以上のときにはアンチモ ンの副スポットが原点に生じ，またスズのテーリングも 大きい. 硫化アンモニウム溶液（黄色）を水で 3 倍以上 に希釈した場合にもこれと同じ結果が得られた. 30〜 $70 \%$ の範囲では展開距離 $5 \mathrm{~cm}$ (展開時間約 30 分) で アンチモンとスズ，あるいはヒ素とスズの相互分離が酸 化数に関係なく可能である. Fig. 2 にとの分離図形を示 +).

\section{$3.32,4,6$-コリジン添加による影響}

硫化アンモニウム溶液 (黄色)-ピリジン系の展開溶媒 


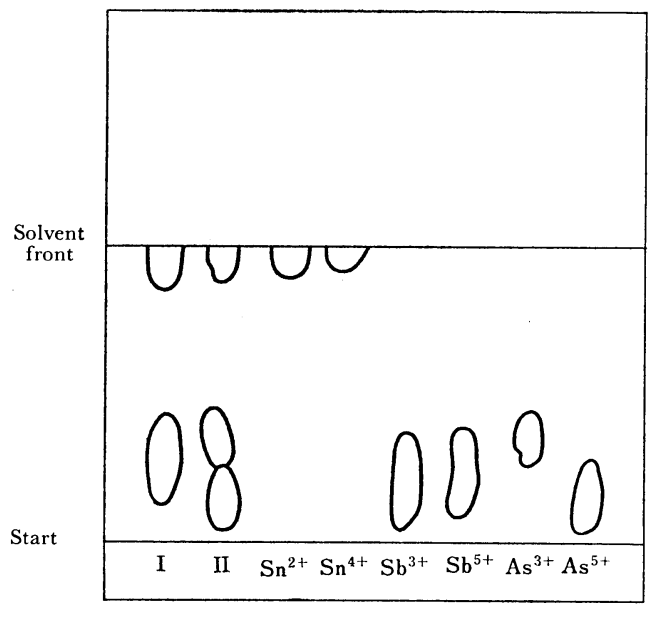

Concn. of callidine

Fig. 2 Paper chromatogram of $\mathrm{Sn}, \mathrm{Sb}$ and $\mathrm{As}$

Solvent: A mixture of ammonium sulfide solution (yellow) and pyridine $(2: 3 \mathrm{v} / \mathrm{v})$; Mixture I : Sn(II, IV) and $\mathrm{Sb}(\mathrm{III}, \mathrm{V})$; $\quad$ Mixture II : $\mathrm{Sn}(\mathrm{II}, \mathrm{IV})$ and As(III, V)

の中へ添加する有機溶媒の種類と量について検討した. その結果, メタノール, エタノール, アセトン, メチル エチルケトンなどのように水との混合が自由である溶媒 についてはスポットの拡散，テーリングが認められた. ブタノール，酢酸ブチル，2,4,6-コリジンなどを少量添 加した場合にはスポットの拡散が減少する効果が認めら れた。

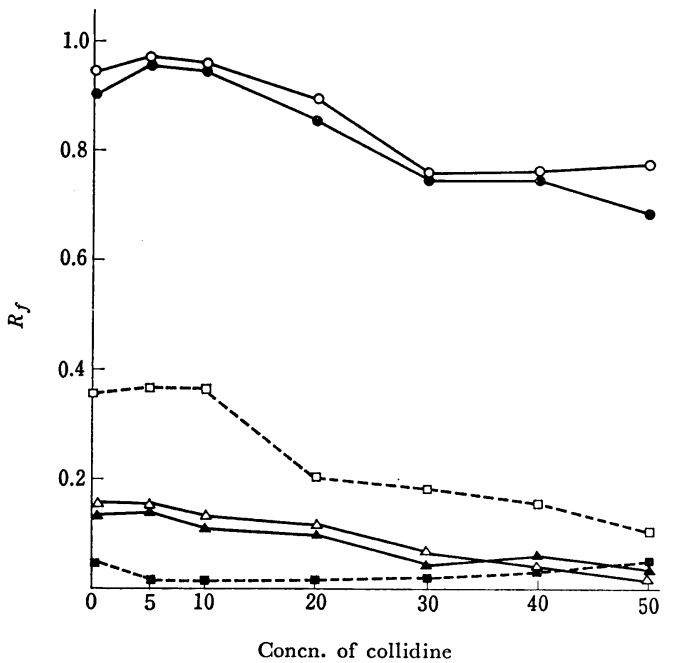

Fig. 3 Effect of amounts of collidine

Solvent : A mixture of ammonium sulfide solution (yellow), $35 \%$, pyridine $(65-a) \%$ and collidine $a \%$; -O- Sn(II); -O $-\mathrm{Sn}(\mathrm{IV}) ;-\triangle-\mathrm{Sb}(\mathrm{III})$;

-A- Sb(V); --- $\square---A s(I I I) ; \quad-. \square--A s(V)$
Fig. 3 は硫化アンモニウム溶液（黄色）を $35 \%$ とし， 2, 4,6-コリジンを a \% ，ピリジンを（65-a）％とした ときのアンチモン，スズ，七素の $R_{f}$ 值である.

硫化アンモニウム溶液 (黄色)-ピリジン展開溶媒では ヒ素とアンチモンのスポットが長くなるため一部重なる が， 2, 4,6-コリジン 5〜10\% の添加によりアンチモン のスポットが短くなり，分離に良好な結果が得られた.

しかし添加する量が多くなると， アンチモンとヒ素の $R_{f}$ 值は接近し, しかもスズのスポットが長くなるため 相互分離は不可能である.

Fig. 4 は 2.1.2 で調製した標準混合試料によるアン チモン，スズ，七素の分離図形である. スズ(II, IV) については完全に分離するが，七素(III) とアンチモン (III，V) は接近し，展開時間を長くしても分離は不完 全であった、しかし，硫化物の色調が異なるので両者を 区別することは可能であり，混合試料の分析上支障とは ならない。

\section{4 検出限界}

$2 \cdot 1 \cdot 2$ で調製したアンチモン，スズ，ヒ素イオンの試

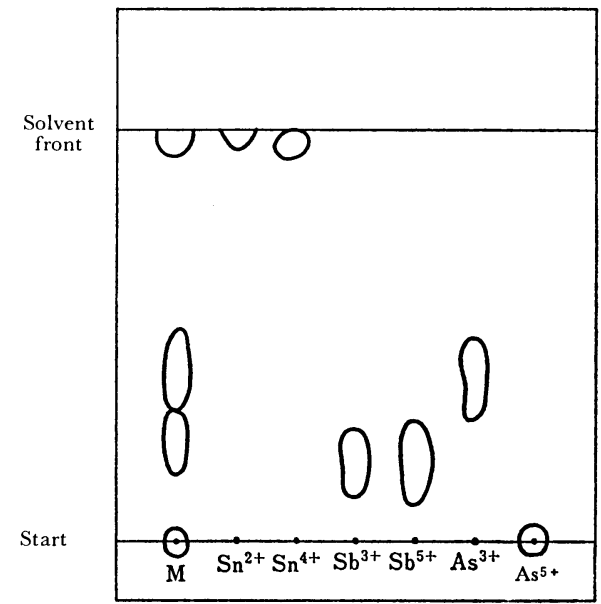

Fig. 4 Separation of $\mathrm{Sb}, \mathrm{Sn}$ and $\mathrm{As}$

Solvent: A mixture of ammonium sulfide solution (yellow), pyridine and collidine $(35: 55: 10 \mathrm{v} / \mathrm{v}) ; \mathrm{M}$ : A mixture of $\mathrm{Sn}(\mathrm{II}, \mathrm{IV}), \mathrm{Sb}(\mathrm{III}, \mathrm{V})$ and $\mathrm{As}(\mathrm{III}, \mathrm{V})$

Table II Identification limits of ions of antimony, arsenic and tin by paper chromatography

\begin{tabular}{lcccccc}
\hline Ions & $\mathrm{Sb}^{3+}$ & $\mathrm{Sb}^{5+}$ & $\mathrm{Sn}^{2+}$ & $\mathrm{Sn}^{4+}$ & $\mathrm{As}^{3+}$ & $\mathrm{As}^{5+}$ \\
$\begin{array}{c}\text { Identification limits } \\
(\mu \mathrm{g} / \mu l)\end{array}$ & 2 & 2 & 1 & 1 & 4 & 4 \\
\hline
\end{tabular}

Solvent : A mixture of ammonium sulfide solution (yellow), pyridine and collidine (35:55:10 v/v) 
Table III Paper chromatographic behavior of various metal ions

\begin{tabular}{|c|c|c|c|c|c|c|c|c|c|c|c|c|c|c|c|c|}
\hline \multirow{2}{*}{ Solvent } & \multicolumn{16}{|c|}{$R_{f}$} \\
\hline & $\mathrm{Sb}^{3+}$ & $\mathrm{Sb}^{5+}$ & $\mathrm{Sn}^{2+}$ & $\mathrm{Sn}^{4+}$ & $\Lambda s^{3+}$ & $\mathrm{As}^{5+}$ & $\mathrm{Cu}^{2+}$ & $\mathrm{Pb}^{2+}$ & $\mathrm{Bi}^{3+}$ & $\mathrm{Cd}^{2+}$ & $\mathrm{Cr}^{3+}$ & $\mathrm{Hg}^{2+}$ & $\mathrm{Fe}^{3+}$ & $\mathrm{Ni}^{2+}$ & $\mathrm{Co}^{2+}$ & $\mathrm{Mn}^{2+}$ \\
\hline A & 0.85 & 0.84 & 0.83 & 0.83 & 0.86 & 0.86 & 0 & 0 & 0 & 0.01 & 0 & 0 & 0 & $0 \mathrm{~T}$ & $0 \mathrm{~T}$ & 0 \\
\hline B & 0.89 & 0.89 & 0.82 & 0.85 & 0.89 & 0.89 & 0.85 & 0 & 0 & 0 & 0 & 0.45 & 0 & $0 \mathrm{~T}$ & $0 \mathrm{~T}$ & 0 \\
\hline C & 0.13 & 0.12 & 0.95 & 0.96 & 0.37 & 0.01 & 0.96 & 0.98 & $0.91 \mathrm{~T}$ & 0.95 & 0 & 0.95 & 0.02 & 0.61 & $0.94 \mathrm{~T}$ & 0.42 \\
\hline
\end{tabular}

A : Ammonium sulfide solution (colorless); B : Ammonium sulfide solution (yellow); $\quad$ : : A mixture of ammonium sulfide solution (yellow), pyridine and collidine $(35: 55: 10 \mathrm{v} / \mathrm{v}) ; \mathrm{T}:$ Tailing

料を $6 N$ 塩酸で希釈し，その $1 \mu l$ を 2.2 の操作法に よって展開し，乾燥後現われる硫化物のスポットの検出 限界について検討した. Table II はとの結果である。

\section{5 その他の金属イオンの挙動}

有色硫化物を生ずる金属イオンの硫化アンモニウム系 展開溶媒による挙動について，上昇法を用いて検討した 結果を Table III に示す.

Table III からも明らかなように，硫化アンモニウム 溶液（無色）を展開溶媒とした場合，ニッケル，コバル トイオンの一部は多硫化物 となりテーリングを生ずる が，他の金属イオンは硫化物として原点にとどまる.乙 たがって多量のニッケル，コバルトイオンを含まない場 合には，アンチモン，スズ，七素イオンを他の金属イオ ンから分離することができる.

また, Table III に示す各金属イオン $(5 \mathrm{mg} / \mathrm{ml} 6 N$ 塩酸) の混合試料 $1 \mu l$ を沪紙上につけ, 上昇法により $7 \mathrm{~cm}$ (約 20 分間) 展開した例を Fig. 5 に示す.

ニッケル，コバルトイオンのテーリングによる妨害に

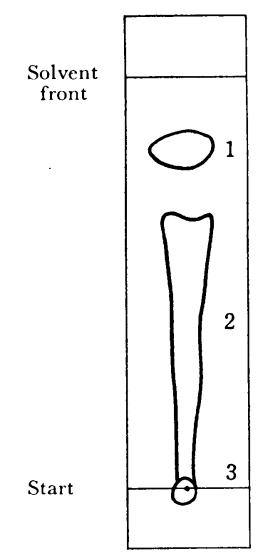

Fig. 5 Paper chromatogram of metal ions

Solvent: Ammonium sulfide solution, colorless; 1 : $\mathrm{Sb}, \mathrm{Sn}$ and As; $2: \mathrm{Ni}$ and Co (tailing); $3: \mathrm{Cu}$, $\mathrm{Pb}, \mathrm{Bi}, \mathrm{Cd}, \mathrm{Cr}, \mathrm{Hg}, \mathrm{Fe}, \mathrm{Ni}$, Co and $\mathrm{Mn}$
ついて検討したところ, $50 \mathrm{mg} / \mathrm{ml}$ 以上のニッケルイオ ンおよび $10 \mathrm{mg} / \mathrm{m} l$ 以上のコバルトイオンを含む場合 には妨害が認められた。

\section{4 結 論}

ペーパークロマトグラフィーによる有色硫化物を生ず る金属イオンについて, 硫化アンモニウム溶液を展開溶 媒として用いた場合の各イオンの挙動について検討し た。

硫化アンモニウム溶液（無色）を用いるとアンチモン， スズ，七素の各イオンを他の金属イオンから分離するこ とが可能である.

アンチモンースズの相互分離には硫化アンモニウム（黄 色)ーピリジン $(2: 3 \mathrm{v} / \mathrm{v})$ が適当であり, 同じ条件でヒ 素ースズの相互分離も可能である.

アンチモンースズーヒ素の相互分離には硫化アンモニウ ム (黄色)-ピリジン-2, 4,6-コリジン (35:55:10 v/v) で展開する. ヒ素(III) とアンチモン (III, V) が接近し ているが色調により区別すれば，スズ(II，IV)，七素 (III)，アンチモン(III，V)，七素(V) の4 群に分離可 能である・

したがって，本法のように硫化アンモニウム（黄色)ピリシンン系の展開溶媒は試料の酸化数をそろえるための 前処理や展開終了後の発色操作の必要がなく, 分析所要 時間も短いので，アンチモンースズーヒ素を含む試料の分 析に有効である.

\section{交献}

1) 原沢四郎：日化，72，423 (1951).

2) 今井 弘: 同上, 80, 878 (1959).

3) I. I. M. Elbeih, J. F. W. McOmie, F. H. Pollard: Disc. Far. Soc., 7, 183 (1949).

4) 田村善蔵：本誌， 1, 117 (1952).

$$
\text { is }
$$

Paper chromatography of ions of antimony, tin and arsenic by the aid of ammonium sulfide. Fumiaki Goshima and Fumie Ishino (Faculty of Education, Gifu University, Shironouchi, Nagara, Gifu-shi, Gifu) 
Metal ions whose sulfides develop color were separated from each other by paper chromatography using a solution of ammonium sulfide (commercia! reagent, JIS first class grade chemical) as a developing solvent.

Antimony, tin and arsenic ions migrated with the solvent as their thionates, whereas other ions remained at the original point as their sulfides. Therefore ions of antimony, tin and arsenic were separated from other metal ions by a solution of ammonium sulfide (colorless).

It is rather difficult to separate tin from antimony by paper chromatography. However the separation was completed by using a mixed solution of ammonium polysulfide and pyridine, regardless of their oxidation numbers.

The sample solution contains $5 \mathrm{mg}$ of each metal ion in $1 \mathrm{ml}$ of $6 N \mathrm{HCl}$.

One microliter of the sample solution was spotted with a capillary tube $1 \mathrm{~cm}$ apart from the end of filter paper (Toyo Roshi, No. 50).

The paper was developed up to $5 \mathrm{~cm}$ by the ascending technique for 30 minutes. The volume ratio of ammonium polysulfide to pyridine was $2: 3$. The paper was dried at room temperature, and then the spots of antimony and tin appeared as their sulfides. The $R_{f}$ values of antimony(II, V) and $\operatorname{tin}(\mathrm{II}, \mathrm{IV})$ are 0.28 and 0.94 .

Arsenic can be separated from tin by the same procedure as antimony separated from tin. 'The $R_{f}$ values of $\operatorname{arsenic}(\mathrm{V})$, arsenic(III) and $\operatorname{tin}(\mathrm{II}, \mathrm{IV})$ are 0.12 , 0.36 and 0.94 , respectively.

When a small amount of 2,4,6-collidine was added in the solvent, antimony can be separated from arsenic. The sample solution contains $2 \mathrm{mg}$ of antimony(III, V) with tin(II, IV) and $5 \mathrm{mg}$ of arsenic(III, V) as each metal ion in $1 \mathrm{ml}$ of $6 \mathrm{~N} \mathrm{HCl}$.

The paper was developed up to $7 \mathrm{~cm}$ by the ascending technique for 60 minutes. The solvent used was ammonium polysulfide, pyridine and 2,4,6-collidine in a $35: 55: 10$ volume ratios. The spot of antimony was in contact with that of arsenic(III) but can be distinguished by their color of sulfides.

Consequently, a mixed solution of ammonium polysulfide and pyridine was effective for the paper chromatographic separation of antimony, tin and arsenic ions.

(Received Aug. 23, 1973)

\title{
加熱食塩を用いる二酸化イオウと硫酸ミストの分別定量
}

\author{
吉森 孝良*，野々村 娍** \\ (1973 作 8 月 31 日受理)
}

\begin{abstract}
硫酸ミストは加熱食塩と反応して塩化水素ガスを生ずるが，二酸化イオウは惊实上反応しないことを 利用して，二酸化イオウと硫酸ミストとを分別定量した.

一定量の硫酸ミストは硫酸水素カリウム標準溶液一定量を, 電気归で $800^{\circ} \mathrm{C}$ まで徐々に加熱分解し て発生させた.二酸化イオウ源としては標準ガスを用いた。

まず, 硫酸ミストの吸収剂について検討した結果, 適当といわれている $80 \%$ イソプロピルアルコー ル水溶液は推奨できず，1\% 過酸化水素水とFig. 1 の静電集じて装置を組み合わせたものが最も適当 であった。

硫酸ミストと二酸化イオウとの混合物を $500^{\circ} \mathrm{C}$ に加熱した食塩と反応させた結果，ミストの $90.4 \%$ と, 二酸化イオウの $3.3 \%$ とが塩化水素ガスに置換した. 二酸化イオウ含量が少ないときは, その転化 率は無視できた.

この方法を実際に鉱石焼結炉とボイラー加熱炉の排ガス分析に応用した.
\end{abstract}

\footnotetext{
1 緒 $\overline{\overline{\bar{n}}}$

大気污染成分であるイオウ酸化物のうち，二酸化イオ

* 東京理科大学工学部 : 東京都新宿区神楽坂 1-3

** 現在 東京都立工業技術センター：東京都北区西ケ 丘 3-13-10
}

ウは水に溶けやすく, その定量は比較的容易であるが, ミスト状のものは水に吸収されにくく定量が困難であ る・また，排ガスに拉てを硫酸ミストの処理は必ずし も容易ではない.

一般に煙道排ガス中の三酸化イオウは，全イオウ酸化 物の 1〜5\% であるといわれている1). また，大㸚中で 